\title{
Influence of Energy on Compaction Characteristics of High Expansive Soils
}

\author{
Talal Masoud, Manal O. Suliman
}

\begin{abstract}
Each soil type has different behavior with regard to determination of maximum dry density and optimum moisture content and therefore any soil type has its own compaction requirements for experimental purposes and for control the compaction in the field. The general purpose of this study is to a better understanding of the compaction characteristics of high expansive soils, with emphasis on the relationships of moisture content and dry density of high expansive soils at a range of compaction energy levels. To achieve this purpose, high expansive soils samples were subjected to Atterberg limit and a set of laboratory compaction tests to find compaction characteristics namely; maximum dry unit weight and optimum water content of high expansive soils at different compaction energy (compaction effort) for different number of hammer blows per each layer range from 10 to 50, which varied the energy per unit volume from 356 $\mathrm{KN} / \mathrm{m} 3$ to $1188 \mathrm{KN} / \mathrm{m} 3$. Rather than single peak compaction curves, the most achieved compaction curves are an irregular one and half peak compaction curves. According to the comparison results of different compaction energy, it was concluded that the maximum dry unit weight of high expansive soil was not highly affected by gradually increase of applied energy. The results showed that, the maximum dry density of tested expansive soils sample increased from $1.48 \mathrm{~g} / \mathrm{cm} 3$ to $1.6 \mathrm{~g} / \mathrm{cm} 3$ with increase of compaction energy from $356 \mathrm{KN} / \mathrm{m} 3$ to $1188 \mathrm{KN} / \mathrm{m} 3$.

Keywords: Compaction energy, Compaction curve, High Expansive soils, Maximum dry density, Optimum moisture content, Standard Proctor.
\end{abstract}

\section{INTRODUCTION}

The improvement of engineering properties of expansive soils is very important for strong durable pavements and foundations. Higher shear strength, lower compressibility, lower volume change and lower permeability are desirable properties for soils as foundation and construction materials.

Soil compaction is common practice in the quality control of engineering construction. It is part of the of construction materials procedures that helps construction engineers to improve the properties of soil. A proper selection of the type of compaction method and specification for compaction according to the soil type can play an important part in the compatibility of the soil.

Revised Manuscript Received on June 30, 2020.

Correspondence Author

Talal Masoud* ,Associate Professor, Civil Engineering department, College of Engineering, Jerash University, Jerash, Jordan, Email : t.masoud@jpu.edu.jo

Manal O. Sulima, Assistant Professor, Associate Professor, Civil Engineering department, College of Engineering, Jerash University, Jerash, Jordan, Email : manal.suliman@jpu.edu.jo

(C) The Authors. Published by Blue Eyes Intelligence Engineering and Sciences Publication (BEIESP). This is an open access article under the CC BY-NC-ND license (http://creativecommons.org/licenses/by-nc-nd/4.0/)
Density moisture content test is usually used test for quality control of construction works. It is one of the soil properties tests that help engineers to planning, design, constructing and maintaining of overall civil engineering infrastructure projects.The process of compaction alters and improves the engineering properties of soils because when soils are compacted to a denser state, they will exhibit higher strength, lower compressibility, and lower permeability. These properties are desirable for strong durable pavements and foundations. Monitoring of density during construction is essential to ensure the high quality and long life of civil works. In field soil compaction, a layer of loose soil is compacted until its density and strength reach specific values established a priori from laboratory tests, due to the benefits from compaction, a larger and heavier machines have been developed for filed compaction to obtain specified characteristics with a minimum amount of energy (work) done and increase the compaction effort which improve the amount of compaction of the soil and enables greater dry unit weights to be achieved. In compaction laboratory tests the increase of compaction effort can be achieved either by using a heavier hammer and (or) using a greater drop height for the compaction hammer.

The compaction effort is controlled by a combination of the parameters such as weight and size of the compactor, the frequency of vibration, the forward speed, the number of roller passes, and the lift height [1].

The compaction effort is one of the most important variables control the compaction behavior of soils. Hence, there is a need to know how the compaction effort affects the soil in compaction process.

Little attention has been directed towards understanding the influence of compaction energy on strength and deformation properties of compacted soil which are directly related to soil type and moisture content.

Much of the literature on influence of compaction energy on soil engineering properties focuses on dry unit weight as a key parameter of research $[2,3,4,5,6]$ and the results of these previous studies show that the maximum dry density considerable depends on soil type, soil moisture content and compaction energy. In this study an experimental program was carried out to assessment the effect of different compaction energies on compaction characteristics of high expansive soil the compaction test was performed by different number of hammer blows per each layer varied from 10 to 50 blows, which result in varied energy per unit volume

Published By:

Blue Eyes Intelligence Engineering \& Sciences Publication

(C) Copyright: All rights reserved. 


\section{Influence of Energy on Compaction Characteristics of High Expansive Soils}

\section{MATERIALS TESTED}

\section{EXPANSIVE SOILS}

The Expansive soil sample used for this research work is prepared in the laboratory by mixing of bentonite and collected expansive clay soil from Jerash city in Jordan from one test pit to prepare high expansive soils. Prior to compaction testing, atterberg limits were determined following (ASTM D 4318) for classification of the soil.

The index properties of the investigated soil sample are presented in Table (1). For classification of expansive soil Chen [7] uses only plasticity index method for identifying expansive soils. Based on Chen classification the used soils sample for compaction test in this study is high plastic clay and high swelling potential soils.

Table 1: liquid limit, plastic limit and plasticity index for high expansive soils used for standard Proctor tests

\begin{tabular}{|c|c|}
\hline Atterberg Limits & Value \% \\
\hline Liquid Limit & $130 \%$ \\
\hline Plastic Limit & $50 \%$ \\
\hline Plasticity Index & $80 \%$ \\
\hline
\end{tabular}

\section{EQUIPMENT USED AND TESTING PROCEDURES}

Standard Proctor test equipment that used in this study was identical to that specified in ASTM D 698. The Standard Proctor compaction test was performed following the compaction procedures for the appropriate mold size used. A representative water content sample was taken from each compacted specimen and the water content was determined following ASTM D 2216. In the lab, specimens were compacted into the $944 \mathrm{Cm} 3$ of mass (standard Proctor mold); the number of layers of soil used for compaction was three of approximately equal mass for all cases over a wide range of moisture contents at each energy level to determine dry unit weight. However, the number of hammer blows per each layer varied from 10 to 50 , which varied the energy per unit volume. Table (3) shows the different applied energy to high swelling clay samples. The compaction effort is the amount of energy or work necessary to induce an increment in the density of the soil. The measurement of the compaction effort is specific energy value (E); applied energy per unit volume .The compaction energy per unit volume used for the standard Proctor test described in:

$\mathrm{E}=$

$\frac{\left(\begin{array}{c}\text { Number of } \\ \text { blows per layer }\end{array}\right) \times\left(\begin{array}{c}\text { Number of } \\ \text { layers }\end{array}\right) \times\left(\begin{array}{c}\text { Weight of } \\ \text { hammer }\end{array}\right) \times(\text { Height of drop of hammer })}{\text { Volume of mold }}$

Or, in ISI units,

$E=\frac{(25) \times(3) \times\left(\frac{2.5 \times 9.81}{1000} \mathrm{KN}\right) \times(0.305 \mathrm{~m})}{944 \times 10^{-6} \mathrm{~m}^{2}}=594 \mathrm{KN}-\mathrm{m} / \mathrm{m}^{2} \approx 600 \mathrm{KN}-\mathrm{m} / \mathrm{m}^{2}$

\section{RESULT AND DISCUSSION}

\section{A. Compaction Curve}

The compaction curve represents the dry densities versus the water contents obtained from a compaction test.

Four types of compaction curves as shown in "Fig. 1" Can be observed for different types of soils based on the value of liquid limit these curves are single peak curve type $\mathrm{A}$, one-and-one-half-peak curve type $\mathrm{B}$, double-peak curve type C, and odd shape curve type D ,Lee and Suedkamp [8], Das [9]

After obtaining density and moisture of each compacted soil samples, the following relationships for dry density and moisture content that obtained are illustrates in "Figs.2 to8" below. It's clearly from the results obtained in this study the most compaction curves for tested soil samples under different compaction energy have irregularly shape.

Based on types of compaction curves illustrated above, "Fig. 2", is odd ship curve, "Fig. 3", is a single peak curve, "Fig. 4", clearly showed double peaks compaction curve, while "Figs. 5,6,7", showed one and half peak compaction curves as show in these curves a very high dry density is obtained at the lowest water content which mean the highest dry density is obtained at the dry side of the compaction curves for high expansive clay.

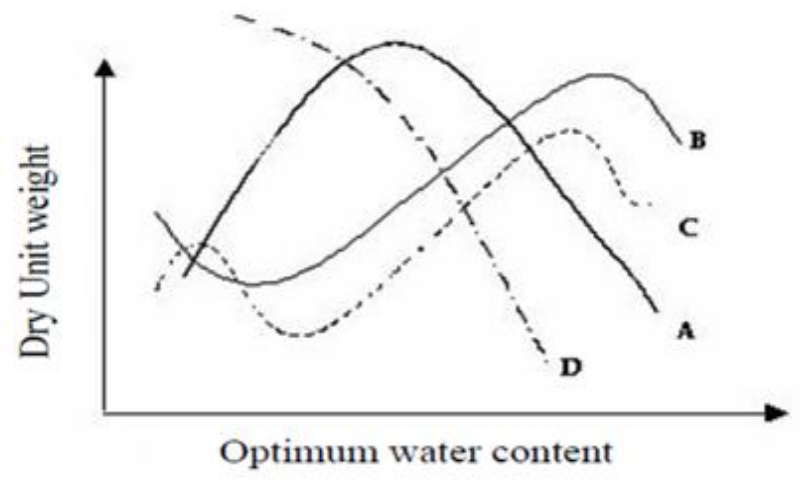

Fig. 1.Types of Compaction Curves Das[8]

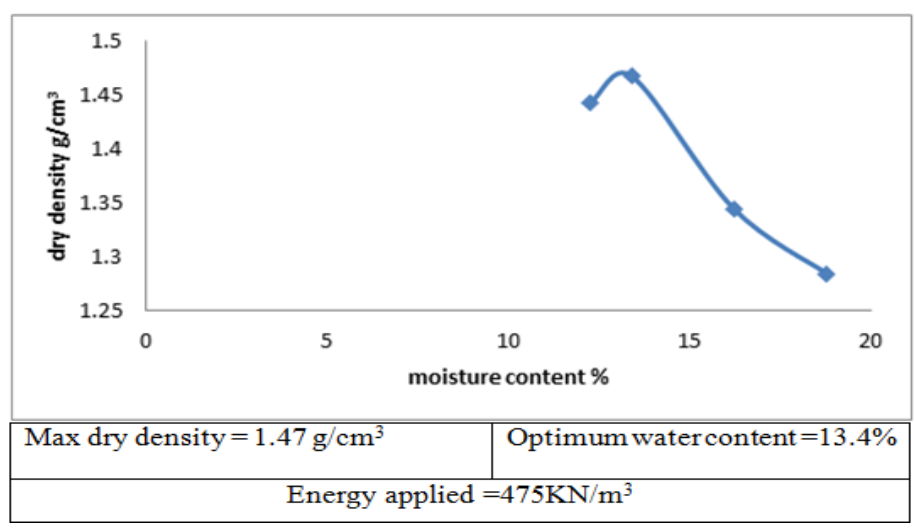

Fig. 2.Compaction curve for applied energy 356KN/m3
Published By:

Blue Eyes Intelligence Engineering \& Sciences Publication (C) Copyright: All rights reserved. 

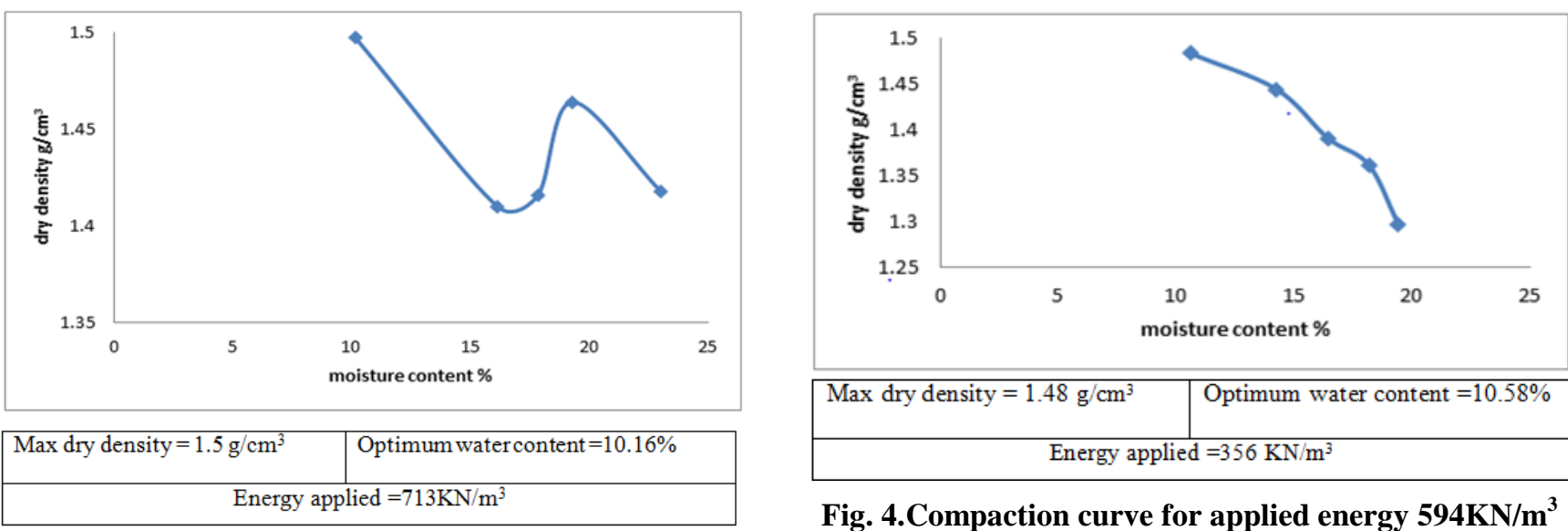

Fig. 3.Compaction curve for applied energy $475 \mathrm{KN} / \mathrm{m}^{3}$

Fig. 4.Compaction curve for applied energy $594 \mathrm{KN} / \mathrm{m}^{3}$

Table- II: Compaction energy applied to high swelling clay specimens

\begin{tabular}{|c|c|c|c|c|c|c|}
\hline Compaction test & $\begin{array}{l}\text { Volume of } \\
\text { Mould } \\
\mathrm{Cm}^{3}\end{array}$ & $\begin{array}{l}\text { No of } \\
\text { compacted } \\
\text { layer }\end{array}$ & $\begin{array}{l}\text { Hammer } \\
\text { blows per } \\
\text { each layer }\end{array}$ & $\begin{array}{l}\text { Hammer } \\
\text { mass } \\
\text { kg }\end{array}$ & $\begin{array}{l}\text { Height of } \\
\text { Hammer fall cm }\end{array}$ & $\begin{array}{l}\text { Energy } \\
\text { applied } \\
\mathrm{KN} / \mathrm{m}^{3}\end{array}$ \\
\hline \multirow{7}{*}{$\begin{array}{l}\text { Standard compaction } \\
\text { test }\end{array}$} & \multirow{7}{*}{944} & 3 & 15 & 2.5 & 30.5 & 356 \\
\hline & & 3 & 20 & 2.5 & 30.5 & 475 \\
\hline & & 3 & $\begin{array}{c}25 \\
\text { (Standard) }\end{array}$ & 2.5 & 30.5 & 594 \\
\hline & & 3 & 30 & 2.5 & 30.5 & 713 \\
\hline & & 3 & 35 & 2.5 & 30.5 & 832 \\
\hline & & 3 & 40 & 2.5 & 30.5 & 950 \\
\hline & & 3 & 50 & 2.5 & 30.5 & 1188 \\
\hline
\end{tabular}

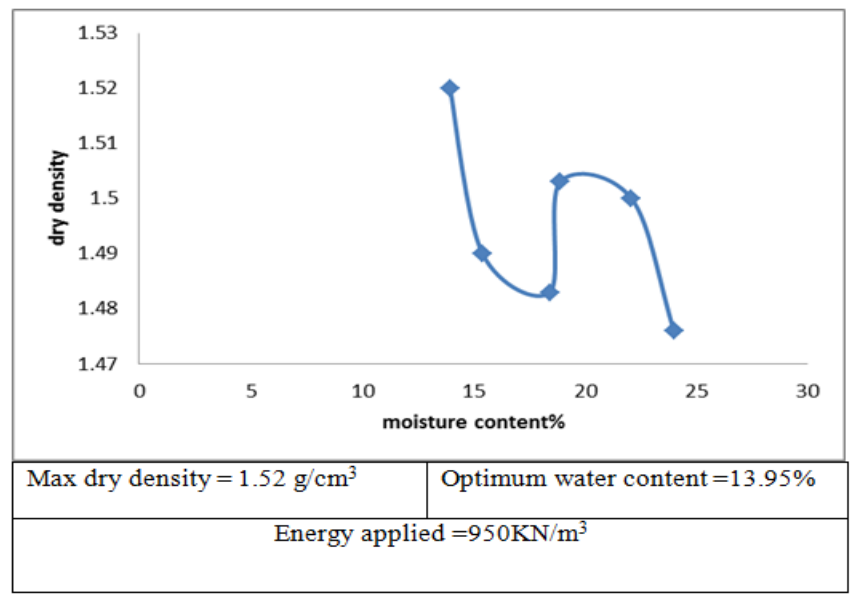

Fig. 5.Compaction curve for applied energy $713 \mathrm{KN} / \mathrm{m}^{3}$

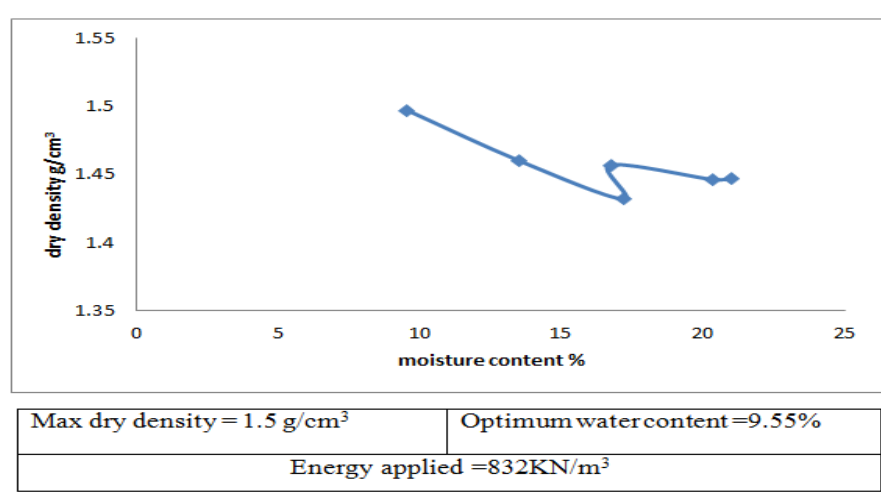

Fig. 6.Compaction curve for applied energy $832 \mathrm{KN} / \mathrm{m}^{3}$

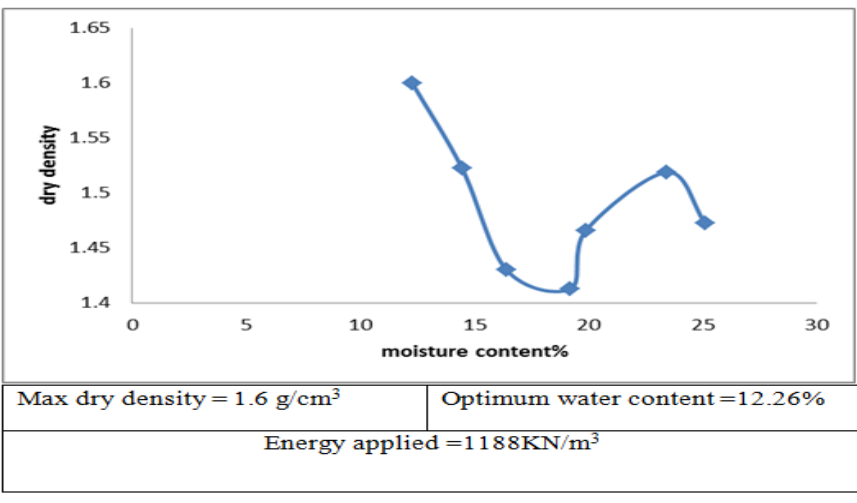

Fig. 7.Compaction curve for applied energy $950 \mathrm{KN} / \mathrm{m}^{3}$

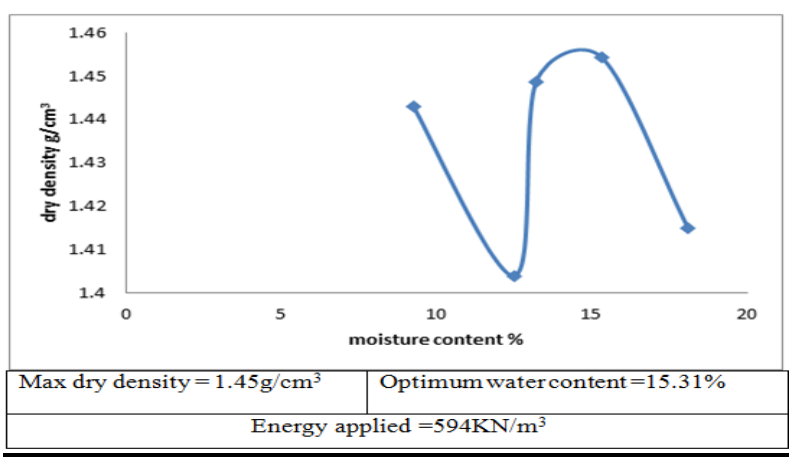

Fig. 8.Compaction curve for energy applied 1188 KN/m

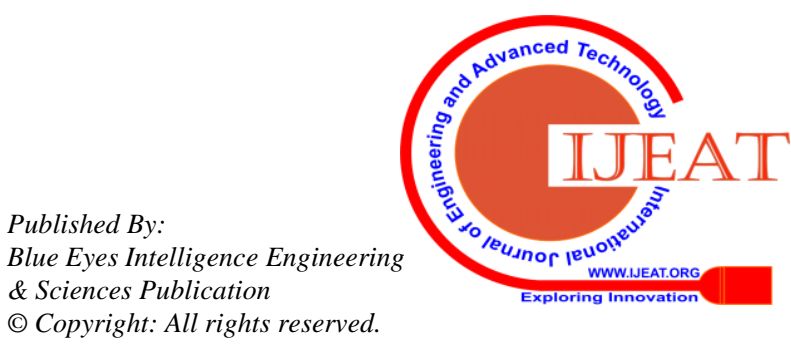




\section{B. Effect of Compaction Energy}

The compaction curves which illustrated above demonstrated that as the compaction effort per unit volume of soil are changed, the moisture-density curve also changes.

The values of maximum dry density for tested soils sample under different compaction energy have been summarized in table 4, and "Fig. 9" below. From the preceding observation the results below demonstrated that as the compaction energy is increased, the maximum dry unit weight of compaction is also increased to some extent.

Variations of dry density with different applied compaction energy are presented in "Figs. 9,10". As shown in the figure the dry density of the high expansive soils sample stared to decrease with increase of compaction energy until reached the energy of standard Proctor test $600 \mathrm{KN} / \mathrm{m} 3$ after that the dry density stared increase with increase of applied energy. The higher dry density from most results compaction curves is obtained at the dry side of the compaction curves for high expansive soils sample. Generally very slight increment of dry density (from $1.48 \mathrm{~g} / \mathrm{cm} 3$ to $1.6 \mathrm{~g} / \mathrm{cm} 3$ ) were observed compares to increment of applied energy (from356 KN/m3 to1188 $\mathrm{KN} / \mathrm{m} 3$ ), this mean that the high expansive soils are not highly affected by the increase of compaction energy .

Table 4: The relation between maximum dry density and compaction energy for compacted high expansive soil

\begin{tabular}{|l|l|l|l|l|l|l|l|}
\hline $\begin{array}{l}\text { Compaction energy } \\
\mathbf{K N} / \mathbf{m}^{3}\end{array}$ & $\mathbf{3 5 6}$ & $\mathbf{4 7 5}$ & $\mathbf{5 9 4}$ & $\mathbf{7 1 3}$ & $\mathbf{8 3 2}$ & $\mathbf{9 5 0}$ & $\mathbf{1 1 8 8}$ \\
\hline $\begin{array}{l}\text { Maximum dry } \\
\text { density g/cm }\end{array}$ & 1.48 & 1.47 & 1.45 & 1.5 & 1.5 & 1.52 & 1.6 \\
\hline
\end{tabular}

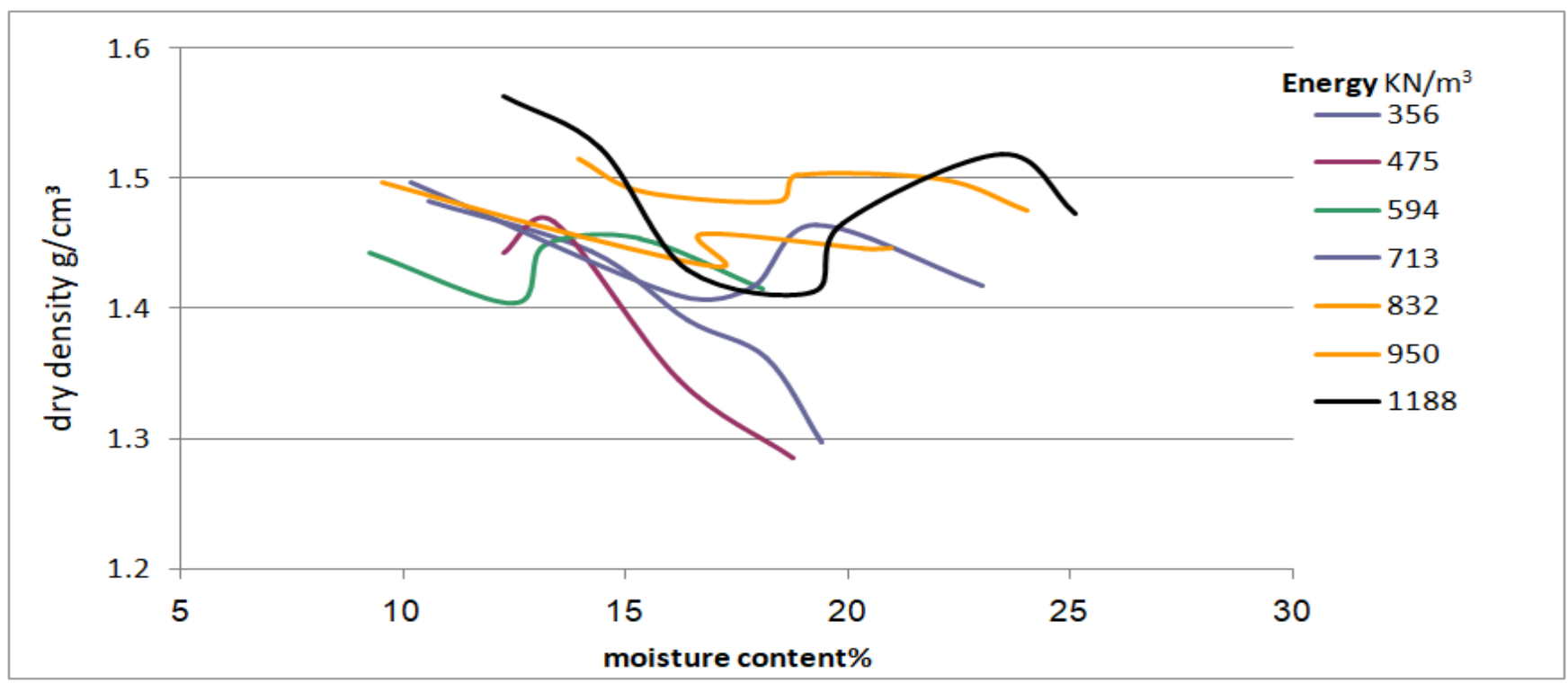

Fig. 9.Compaction Curves for compacted high expansive soils at different compaction energy

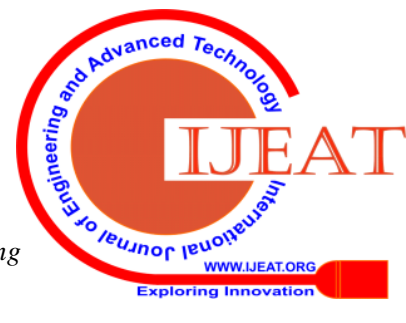




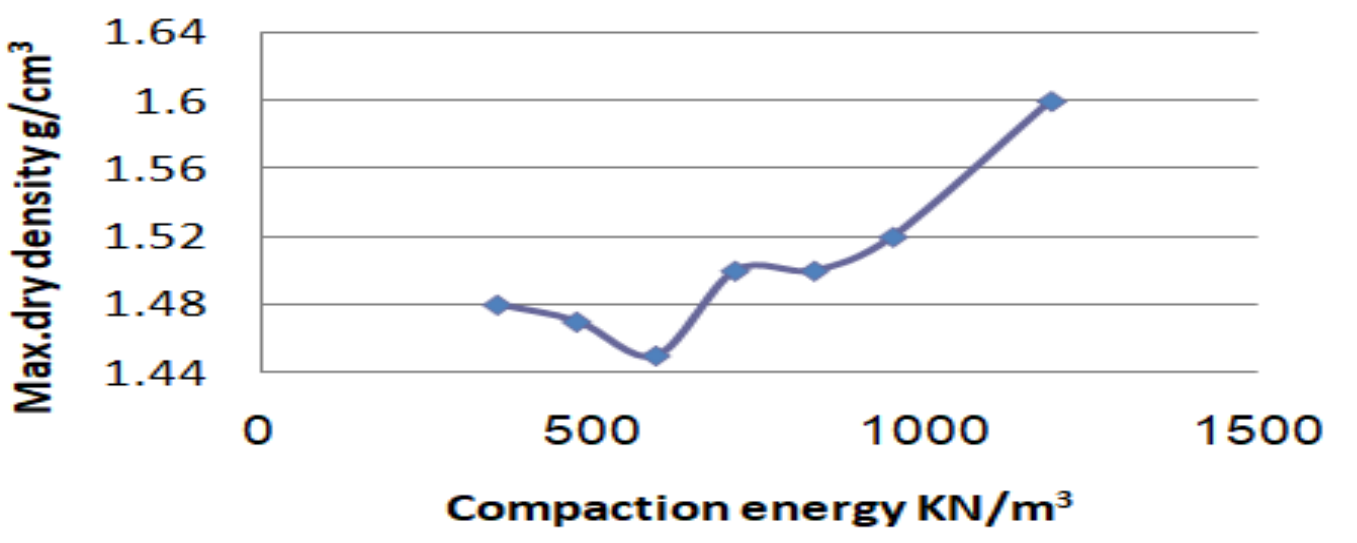

Fig. 10.Relationship between compaction energy and maximum dry density

\section{CONCLUSION}

Study the different geotechnical properties of various soils types is very important to the construction engineer. In this laboratory investigation, dry unit weight and moisture content parameters of high expansive soils with L.L $=130 \%$, and $\mathrm{PI}=80 \%$, were evaluated as a function of compaction energy.

Compaction curves results for high expansive soils sample used in this study from the lab

standard compaction tests at different compaction energy were showed irregularly shaped compaction.

According to this study, rather than single-peak compaction curve the most results compaction curves indicated a one and half-peak curve, and a double-peak compaction curve, and the highest dry density for the most soil sample is obtained at the dry side of the compaction curves.

Determination of optimum water content which achieves the maximum dry density for this soil could present a problem to the civil engineer.

The maximum dry unit weight of high expansive soils sample used in this study was not highly affected by the increase of compaction energy but generally, the maximum dry unit weight increased as compaction energy increased, although the change of maximum dry unit weight is small, as it's found that the maximum dry density of tested high expansive soil samples increased from $1.48 \mathrm{~g} / \mathrm{cm} 3$ to 1.6 $\mathrm{g} / \mathrm{cm} 3$ with compaction energy increase from $356 \mathrm{KN} / \mathrm{m} 3$ to $1188 \mathrm{KN} / \mathrm{m} 3$.

The engineering properties of high expansive soils have to be studied in detail including their strength parameters.

\section{REFERENCES}

1- D'Appolonia, D. J., Whitman, R. V., and D'Appolonia, E. D. "Sand compaction with vibratory compaction equipment". Journal of Soil Mechanics and Foundations Division, 95(1), 1969, pp. 263-284.

2- Sabat, A. K., \&Moharana, R. K "Effect of Compaction Energy on Engineering Properties of Fly Ash-Granite Dust Stabilized Expansive Soil", 2015.

3- S.R. Jolly, and P.Vinod, "Effect of compactive energy on compaction characteristics of soil" Proceedings of Indian Geotechnical Conference,2012, pp.143-146.

4- Amarnath, M. S. "Strength and performance characteristics of soil compacted at different energy levels". International Journal of Earth Sciences and Engineering, 2012, pp 347-351.
5- Horpibulsuk ,S., Rachan R., and Kaktan W."Prediction of compaction curves at various energies using one point method". International Symposium on Low Lowel Technology,Saga, Japan,2006.

6- Talal Masoud, HeshamAlsharie, Ahmad Qasaimeh. "Energy Analysis for the Compaction of Jerash Cohesive Soil".Computational Water, Energy, and Environmental Engineering, 2015,4, pp.1- 4.

7- Chen, F. H."Foundation on Expansive Soils", Elsevier Co. Amsterdam.

8- Lee, P.Y., and Suedkamp, R.J. "Characteristics of irregularly shaped compaction curves of soils". Journal of Highway Research Record, 1975.

9- Das, B. M. Principles of Geotechnical Engineering. Seventh Edition.Cengage Learning, USA.

10- Gurtug, Y., and Sridharan, A. "Compaction behaviour and prediction of its characteristics of fine-grained soils with particular reference to compaction energy". Journal of Soil and Foundations, 2004, pp. 27-36.

11- Holtz, R. D., Kovacs, W. D and Sheahan, T. C. An introduction to Geotechnical engineering. USA: Prentice- Hall.2010.

12- Mujtaba, H., Farooq, K., Sivakugan, N., and Das, B. M. Correlation between Gradation Parameters and Compaction Characteristics of Sandy Soils. Internal Journal of Geotechnical Engineering, 7(4), 2013, pp.395-401.
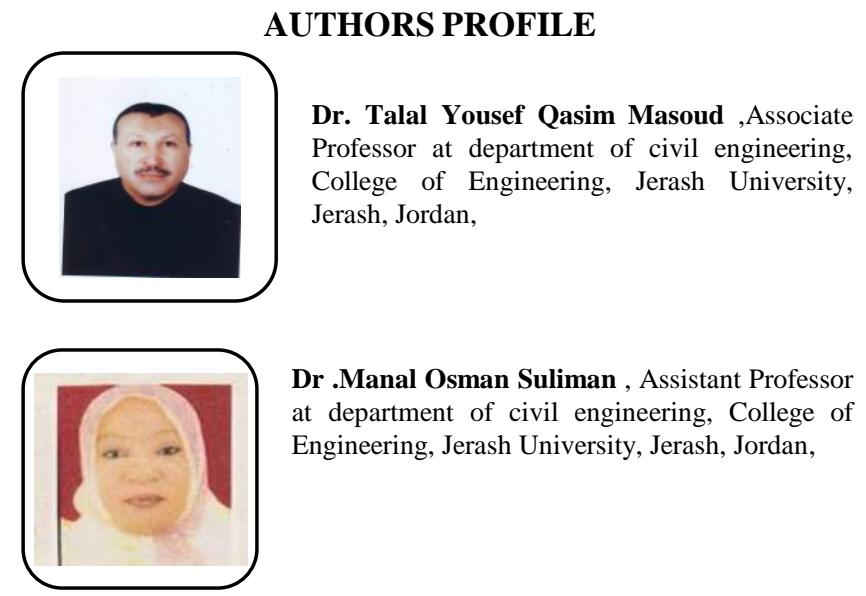

Dr .Manal Osman Suliman , Assistant Professor at department of civil engineering, College of Engineering, Jerash University, Jerash, Jordan,
Published By:

Blue Eyes Intelligence Engineering \& Sciences Publication 